\title{
CHINA'S EXCHANGE RATE AND INTERNATIONAL ADJUSTMENT IN WAGES, PRICES, AND INTEREST RATES: JAPAN DÉJÀ VU?
}

\author{
RONALD MCKINNON \\ GUNTHER SCHNABL \\ CESIFO WORKING PAPER NO. 1720 \\ CATEGory 6: Monetary Policy And InTERnAtional FinANCE \\ MAY 2006 \\ An electronic version of the paper may be downloaded \\ - from the SSRN website: \\ - from the RePEc website: \\ www.SSRN.com \\ - from the CESifo website: \\ www.RePEc.org \\ www.CESifo-group.de
}




\title{
CHINA'S EXCHANGE RATE AND INTERNATIONAL ADJUSTMENT IN WAGES, PRICES, AND INTEREST RATES: JAPAN DÉJÀ VU?
}

\begin{abstract}
China keeps its exchange rate tightly fixed to the dollar. Its productivity growth and trade surplus have been high, and it continues to accumulate large dollar reserves. Many observers take this as evidence that the renminbi is undervalued and should be appreciated to reduce the Chinese trade surplus. We argue that an appreciation of the renminbi need not reduce China's trade surplus but could cause serious deflation in China. To show this, we consider international adjustment between China and the United States from both an asset-market and a labor-market perspective, and compare this to Japan's unsuccessful appreciation of the yen.
\end{abstract}

JEL Code: F15, F31, F33.

Keywords: China, exchange rate, adjustment, assets markets, labour markets.

\author{
Ronald McKinnon \\ Stanford University \\ Stanford, CA 94305-6072 \\ USA \\ mckinnon@stanford.edu
}

\author{
Gunther Schnabl \\ Leipzig University \\ Marschenerstr. 31 \\ 04109 Leipzig \\ Germany \\ schnabl@wifa.uni-leipzig.de
}

May 3, 2006 


\section{Introduction: From Japan to China Bashing}

In the new millennium, expansionary fiscal and monetary policies in the United States and low personal saving have contributed to rising "global imbalances", i.e., a rising U.S. current account deficit financed by heavy borrowing by the United States in dollars from the rest of the world. ${ }^{1}$ Much of the real counterpart of this financial transfer comes from the high-saving East Asian countries collectively running large trade surpluses, mainly in manufactures, with the United States. The trade surpluses of the East Asian countries, in combination with exchange rate stabilization against the dollar, has led to increasing mercantilist pressure from Europe and the United States. In particular, China has come under heavy pressure to appreciate the renminbi (see for instance Goldstein 2003, Cline 2005, and Frankel 2006).

The current U.S.-Chinese trade frictions are reminiscent of U.S.-Japan frictions from the 1970s through to 1995. The rising penetration of Japanese manufactured goods into the American market created trade frictions that led to a political phenomenon popularly known as "Japan bashing". Episodically, the Japanese government responded to American threats of trade sanctions and demands that the yen should appreciate by imposing "voluntary" export constraints on exports to the United States and allowing the yen to appreciate (McKinnon and Ohno 1997 and Schnabl 2000). The yen rose all the way from 360 to the dollar in August 1971 to a peak of 80 to the dollar in April 1995, when worried about the slumping Japanese economy, the U.S. Treasury Secretary, Robert Rubin announced a new "strong dollar" policy after which Japan bashing more or less ceased.

In the new millennium, history is repeating itself, but now China bashing is superseding Japan bashing. But, after the disastrous Japanese precedent of an ever-higher yen, we shall show that

1 Whether it is mainly "undersaving" in the United States or "oversaving" in the rest of the world, particularly Asia, can be debated. For the latter view, see the ingenious argument by Bernanke (2005). For understanding the 
China's exchange rate policy itself best remains unchanged. To analyze the choice of an exchange rate regime in the economic catch-up process, we first focus on the response of interest rates in asset markets, and then go on to consider wage adjustment in labor markets. In contrast to Frankel (2006), we find that adjustment in economic catch-up process is smoother under fixed than flexible exchange rates.

\section{Adjustment in Asset Markets}

In Japan's era of very high economic growth in the 1950s and 1960s, its current account was nearly balanced. The Bank of Japan could fix the yen at 360 to the dollar with surprising little official exchange reserves for two reasons. First, the Ministry of Finance (MOF) tightly controlled capital flows. Second, the United States as the center country was relatively well behaved fiscally and had moderate current account surpluses. Only in the 1980s under President Ronald Reagan, after Japan had loosened its exchange controls and its capital markets became more developed and open, did the U.S. run large fiscal and current account deficits. Then, as now, high-saving Japan was (and is) co-opted into running more or less chronic current account surpluses corresponding to U.S. current account deficits. The corresponding buildup of dollar claims within Japan's financial system then led (leads) to potential portfolio instability between holding yen or dollar assets by Japanese financial institutions.

Unlike Japan in its catch-up phase 30 years earlier, China-while still in the "catch-up" stage of very rapid economic growth, capital controls, underdeveloped domestic financial markets, and low per capita income - has become a major international creditor. Along with other East Asian countries in the new millennium, China is running a large current large current account surplusas shown in Figure 1. How does the consequent buildup of dollar claims affect equilibrium in China's financial markets? 
Figure 1: Current Accounts of China, Japan and US, 1980-2005 (percent of GDP)

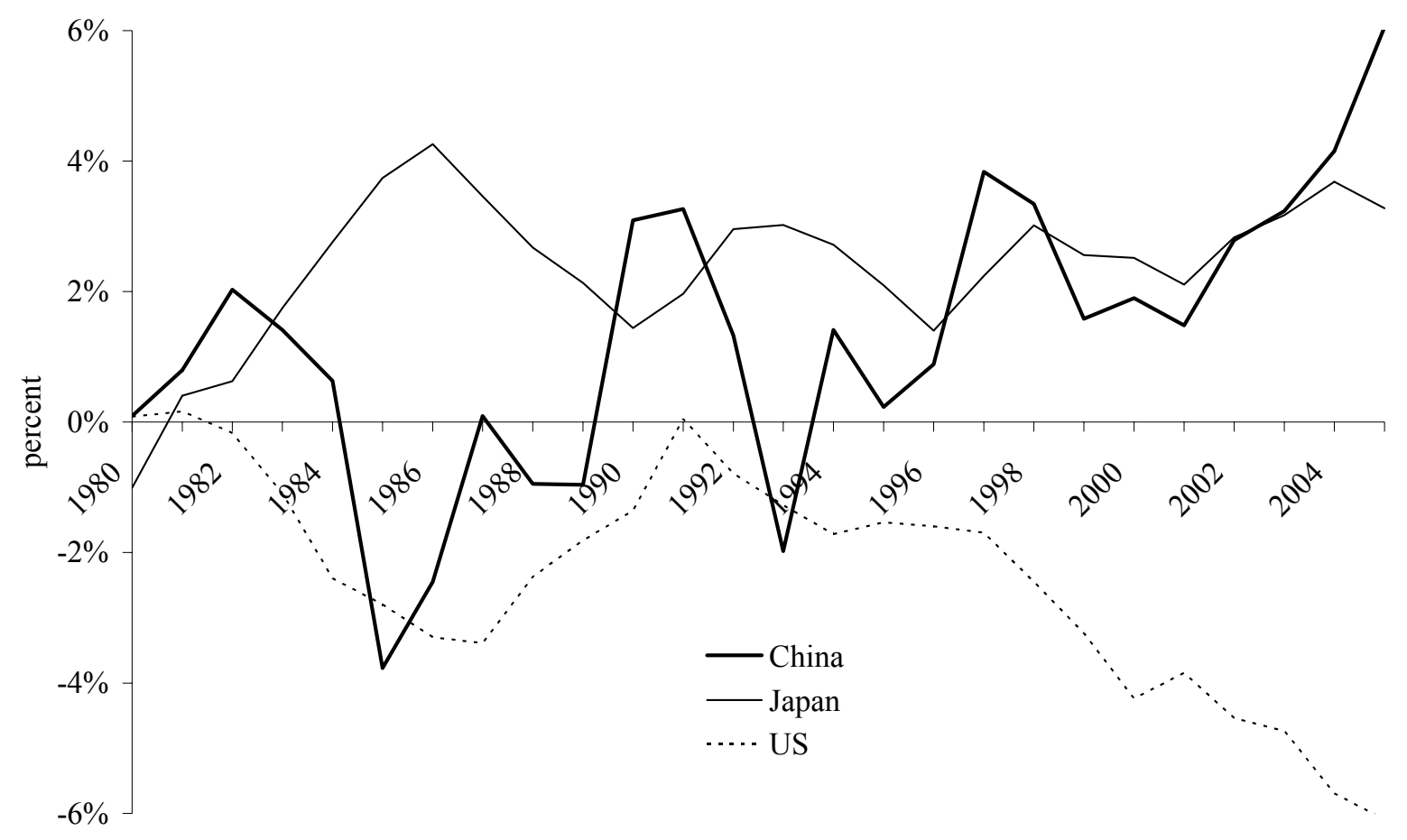

Source: IMF.

\subsection{China's Dollar Overhang}

After becoming positive in 1994, China's net surplus on current account increased steadily up to 6 percent of GDP in 2005 (Figure 1). The surplus reflects China's very high saving - private plus government - even relative to its very high domestic investment. In addition China has attracted a very large amount of FDI. Net FDI flows into China had grown to about 55 billion dollars in the year 2005 (Figure 2). Because FDI results in relatively illiquid liabilities of indefinite duration to foreigners, these do not offset the liquidity effect of the counterpart build up of highly liquid dollar assets by domestic nationals. ${ }^{2}$ Thus the ongoing current-account surplus coupled with huge net inflows of FDI have a double-barreled impact on increasing China's dollar liquidity. In contrast Japan, which is running even a larger current account surplus than China, net FDI flows have been negative.

2 Of course, there would be no liquidity effect if China had a current account deficit that matched the inflow of FDI. 
Figure 2: China: Current Account and Net FDI Inflows, 1980-2005

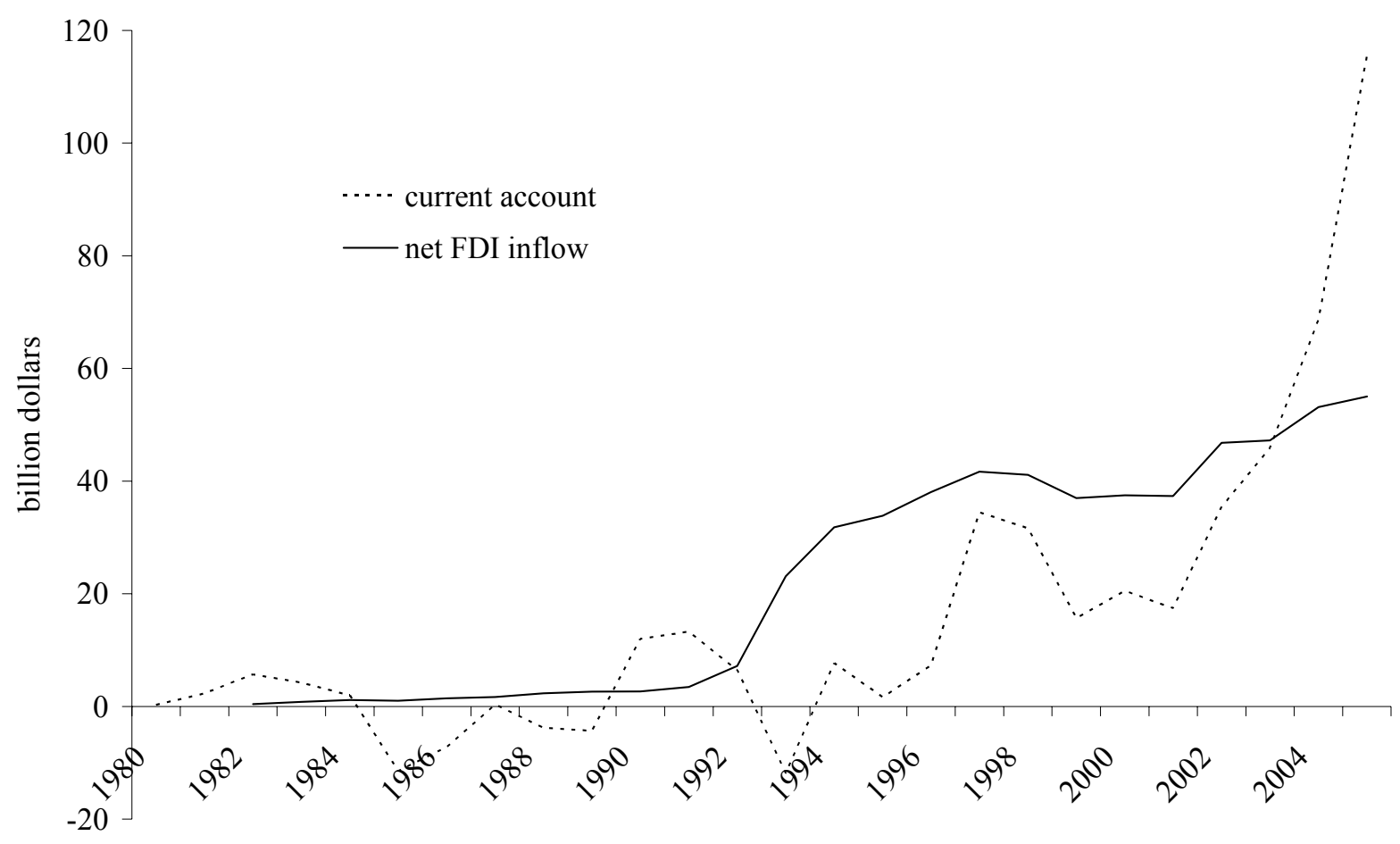

Source: IMF. Net FDI Inflows=Gross FDI Inflows-Gross FDI Outflows.

China's foreign exchange flows and build up of international liquidity can be characterized by a simple balance-of-payments identity. Let CA be the current account surplus and let FDI be the net annual inflow of foreign direct investment. FDI inflows in the form of joint ventures with local enterprises were (are) generally exempt from capital controls. We assume that foreign financial flows into, or out of, China were more restricted. Let $\triangle \mathrm{OER}$ be the change in official exchange reserves, largely U.S. Treasury bonds; and let $\triangle \mathrm{PFA}$ be the change in private foreign assets_-largely dollar claims against banks:

$\triangle \mathrm{PFA}=\mathrm{CA}+\mathrm{FDI}-\Delta \mathrm{OER}$

Integrating backward to 1990 or earlier and assuming no asset valuation adjustments, we then get China's international balance sheet position. 
CHINA: INTERNATIONAL BALANCE SHEET

Liquid Assets

Liabilities and Net Worth

Official Exchange Reserves (OER)

Cumulated Foreign Direct Investment (FDI)

Private Foreign Assets (PFA)

Cumulated Current Account Surpluses (CA)

Table 1 approximates each side of this international balance sheet in more detail. We can estimate China's private and official net holdings of liquid foreign assets both directly and indirectly. First, the right hand side of Table 1 provides indirect estimates of China's liquid foreign exchange assets. For 1990-2005, China's cumulated current account surpluses (column 6) and net FDI inflows (column 7) sum up to 958 billion dollars in 2005 (column 8).

Second, the left hand side of Table 1 shows direct estimates of Chinese holdings of liquid foreign assets. Column 2 is simply current stocks of official net foreign exchange reserves which have grown to 819 billion dollars at the end of 2005. Column (3) is the officially reported net foreign asset position of Chinese commercial banks and other financial institutions. This foreign lending arises of internal dollar bank deposits held by Chinese nationals, 158 billion dollars in 2005 . Column 4 shows cumulative "errors and omissions" that we have reclassified as "cumulative unrecorded capital outflows." 3 By the end of 2005, these cumulative unrecorded capital outflows amounted to US\$ 100 billion, but had declined from their peak of \$US 153 billion in 2001. From 2001 to 2005, there had been net repatriation of dollar assets that had previously been held abroad. The total of column (2) to (4) was US\$1077 billon at the end of 2005 (column 5). This very rough estimation of China's holding of liquid foreign currency claims on foreigners does line up remarkably closely with our indirect estimate of $\$ 958$ billion from the right hand side of Table 1 and corresponds to about $50 \%$ of GDP.

Notice that official exchange reserves are increasing more rapidly and in 2005 were about 80 percent of total liquid claims on foreigners. The private or "nonstate" sector in China has become increasingly reluctant to hold dollar-denominated assets in the face of threats to have the dollar depreciate against the renminbi. Although the statistical dimensions of China's huge and rapidly 
rising stock of international liquidity are clear enough, what motivates China's government (and those in other East Asian countries) to peg to the dollar and accumulate such a large stock of dollar assets?

Table 1: Estimations of Chinese Liquid Net International Assets, 1990-2004 (billion dollars)

\begin{tabular}{|c|c|c|c|c|c|c|c|c|}
\hline & (1) & (2) & (3) & (4) & (5) & (6) & (7) & (8) \\
\hline & $\begin{array}{l}\text { Total Net } \\
\text { Foreign } \\
\text { Assets } \\
\text { (Banking } \\
\text { Sector) }\end{array}$ & $\begin{array}{c}\text { Official } \\
\text { Reserves }\end{array}$ & $\begin{array}{c}\text { Net } \\
\text { Foreign } \\
\text { Assets of } \\
\text { Banking } \\
\text { Institutions }\end{array}$ & $\begin{array}{l}\text { Cumula- } \\
\text { tive Un- } \\
\text { recorded } \\
\text { Capital } \\
\text { Outflows }\end{array}$ & $\begin{array}{c}\text { Total Liquid } \\
\text { Foreign } \\
\text { Assets }\end{array}$ & $\begin{array}{l}\text { Cumula- } \\
\text { tive } \\
\text { Current } \\
\text { Account } \\
\text { Surplus }\end{array}$ & $\begin{array}{l}\text { Cumula- } \\
\text { tive Net } \\
\text { Inward } \\
\text { FDI to } \\
\text { China }\end{array}$ & $\begin{array}{c}\text { Alternative } \\
\text { Estimate of } \\
\text { Liquid } \\
\text { Foreign } \\
\text { Assets }\end{array}$ \\
\hline & & & & & $(2)+(3)+(4)$ & & & $(6)+(7)$ \\
\hline 1990 & 21.7 & 28.6 & 5.1 & 3.1 & 36.8 & 12.0 & 2.7 & 14.7 \\
\hline 1991 & 27.4 & 42.7 & 1.1 & 9.9 & 53.6 & 25.3 & 6.1 & 31.4 \\
\hline 1992 & 30.6 & 19.4 & 6.4 & 18.1 & 44.0 & 31.7 & 13.3 & 44.9 \\
\hline 1993 & 38.6 & 21.2 & 11.7 & 27.9 & 60.8 & 19.8 & 36.4 & 56.2 \\
\hline 1994 & 58.8 & 51.6 & 7.1 & 37.7 & 96.5 & 27.4 & 68.2 & 95.6 \\
\hline 1995 & 76.5 & 73.6 & -3.4 & 55.6 & 125.7 & 29.0 & 102.0 & 131.1 \\
\hline 1996 & 110.7 & 105.0 & -4.3 & 71.1 & 171.8 & 36.3 & 140.1 & 176.4 \\
\hline 1997 & 164.8 & 139.9 & 5.2 & 102.4 & 247.5 & 70.7 & 181.8 & 252.5 \\
\hline 1998 & 181.7 & 145.0 & 17.9 & 121.3 & 284.1 & 102.7 & 222.9 & 325.2 \\
\hline 1999 & 205.7 & 154.7 & 31.0 & 136.3 & 322.0 & 118.3 & 259.9 & 378.1 \\
\hline 2000 & 243.0 & 165.6 & 59.6 & 148.2 & 373.4 & 138.8 & 297.3 & 436.1 \\
\hline 2001 & 319.1 & 212.2 & 85.4 & 153.0 & 450.6 & 156.2 & 334.7 & 490.9 \\
\hline 2002 & 383.4 & 286.4 & 107.8 & 145.2 & 539.5 & 191.6 & 381.5 & 573.1 \\
\hline 2003 & 455.7 & 403.3 & 85.4 & 126.8 & 615.5 & 237.5 & 428.7 & 666.2 \\
\hline 2004 & 668.5 & 609.9 & 108.1 & 102.1 & 820.2 & 307.5 & 484.3 & 792.0 \\
\hline 2005 & 924.3 & 818.9 & 157.5 & 100.9 & 1077.2 & 421.5 & 536.8 & 958.4 \\
\hline
\end{tabular}

Source: IMF.

\footnotetext{
3 For instance, un-repatriated export earnings, surreptitious transfers of money into foreign bank accounts in Hong Kong etc.
} 


\subsection{The Dollar Exchange Rate Trap and Conflicted Virtue}

Outside of Europe, the dollar is the prime invoice currency (unit of account) in international trade in goods and services. All primary products are invoiced in dollars and a few mature industrial countries invoice some of their exports of manufactured goods and services in their own currencies. Because most East Asian countries (including partially Japan) invoice their trade in dollars, these countries collectively are a natural dollar area (McKinnon 2005).

For three closely related reasons, each East Asian country has a strong incentive to peg to the dollar, either formally or informally. First, as long as the U.S. price level remains stable pegging to the dollar anchors the domestic price level. The ambit of dollar invoiced trade with neighbors in East Asia is now much greater than that with the United States itself (McKinnon and Schnabl 2004a, McKinnon 2005). Thus the anchoring effect for any one country pegging to the dollar is stronger because East Asian trading partners are pegging to the dollar as well. Second, East Asian countries are strong competitors, particularly in manufactures, in each other's markets as well as in the Americas and Europe. No one East Asian country wants its currency to suddenly appreciate. This would lead to a sharp loss in mercantile competitiveness in export markets, followed by a general slowdown in its economic growth and possibly deflation. Third, with a large internal overhang of dollar assets, a "free' float runs the risk of triggering a sell off: a run into the domestic currency resulting in an indefinite upward spiral in the exchange rate with no well-defined upper bound.

\section{The Unpredictable Trade Effects of Appreciation}

The macroeconomic repercussions of a sharp discrete appreciation against the world's dominant money are so strong that the effect on the appreciating country's trade balance is ambiguous. True, as its exports become more expensive in dollar terms, they would decline. But as the economy slows, it would import less. The impact on the net trade balance is unpredictable (McKinnon and Ohno, 1997 chs. 6 and 7, Schnabl 2000, chap. 4, and Qiao 2005). When Japan was forced into appreciating the yen several times from the mid-1980s into the mid-1990s, it was thrown into a decade-long deflationary slump with no obvious decline in its large trade surplus, which has persisted up to the present. 
McKinnon and Schnabl (2006) show why the common presumption that a discrete exchange rate change by itself would have a predictable effect on a country's trade balance is often incorrect. This presumption has been canonized in a model called the elasticities approach to the balance of trade that focuses on relative price effects. Because an appreciating country's exports obviously become more expensive in world markets and decline, whereas imports become cheaper, it seems intuitively plausible that its trade surplus should diminish. The proponents of the elasticities approach focus on these relative price effects of an exchange rate change and either ignore the income (absorption) effects or believe them to be small and controllable. But under the world dollar standard where foreign trade and asset flows are largely invoiced in dollars, a peripheral country will be exposed to major income and wealth effects in response to exchange rate changes. In particular, for a creditor country of the United States with a large stock of dollar assets, an appreciation against the dollar would have unacceptable deflationary consequences without correcting the U.S. trade and current account deficits (Qiao 2005).

Among financially open economies, nominal exchange rates and national monetary policies are mutually determined. If a discrete exchange rate change is to be sustained, it must reflect relative monetary policies expected in the future: relatively tight money and deflation in the appreciated country and relatively easy money with inflation in the country whose currency depreciates. After a sharp appreciation, multinational as well as national firms will see the country as a less good (more expensive) place in which to invest so that investment slumps. In creditor countries that have built up large dollar claims on foreigners, this deflationary impact of an exchange appreciation is further accentuated because these dollar assets lose value in terms of the domestic currency: a negative wealth effect that reduces consumption as well as investment. In summary, depressed domestic spending offsets the relative price effect of an appreciation so as to leave the effect on the net trade balance indeterminant. ${ }^{4}$

4 In dollar debtor countries facing the threat of having their currencies depreciate against the dollar, the negative wealth effect tends to reinforce the relative price effect of an actual devaluation. Their trade balances could improve sharply from devaluation as domestic consumption (and imports) slumps even as their now cheaper exports expand into world markets. This was the case for Indonesia, Korea, Malaysia, Philippines, and Thailand after the Asian crisis of 1997-98. Their current accounts went from being sharply negative before the crisis to positive immediately afterwards. 


\section{Conflicted Virtue}

Because the international assets (or debts) of the East Asian countries are denominated in U.S. dollars, they have strong incentive to keep the exchange rate stable (McKinnon and Schnabl 2004b). In creditor countries, the currency risk, i.e., the risk that the dollar will fluctuate against the domestic currency, increases as the domestically held stock of dollar claims becomes larger. The natural currency habitat of domestic nationals is their home currency — unless the country has an unusually flamboyant financial history of debasing the national money, as in some Latin American, African and CIS countries. But China has had a relatively stable financial history. Household consumption expenditures are in yuan, wages are paid in yuan, and claims on financial intermediaries such as banks (deposits) and insurance companies (annuities) are mainly in yuan. Unsurprisingly, households and enterprises seek to hold most of their liquid wealth in domestic currency, the real purchasing power of which over domestic goods and services has been quite stable.

Chinese firms and households will hold dollar assets only if there is a substantial business convenience in doing so, or the interest rate on dollar assets is higher, or they see a political need to hold dollar assets illegally offshore. The primary downside risk is for the yuan to appreciate against the dollar, and thus reduce the yuan value of their dollar assets. Depending on how sensitive domestic holders of dollar assets are to this risk, periodic runs from dollars into yuan could occur just on rumors of appreciation. ${ }^{5}$

However, for the world economy at large, the problem is more general. Any international creditor country that cannot lend in its own currency cumulates a currency mismatch that we call the syndrome of conflicted virtue (McKinnon and Schnabl 2004b, McKinnon 2005). Countries that are "virtuous" by having a high saving rate (like Japan, China or South Korea, but unlike the United States) tend to run surpluses in the current account of their international balance of payments, i.e., lend to foreigners. But, with the passage of time, two things happen. First, as the stock of dollar claims cumulates, domestic holders of dollar assets worry more about a self-

5 Notice that foreigners whose domestic currency habitat is dollars, or tied to the dollar, will be less sensitive. Only foreign professional speculators (or Chinese expatriates) would go out of their way to circumvent China's 
sustaining run into the domestic currency forcing an appreciation. Second, foreigners start complaining that the country's ongoing flow of trade surpluses is unfair, and results from an undervalued currency.

Of course both interact. The greater are foreign mercantilist pressures for appreciation of the domestic currency, the greater is the concern of the domestic holders of dollar assets. As runs out of dollars into the domestic currency begin, the government is "conflicted" because appreciation could set in train serious recession and deflation-particularly if the domestic price level was already stable or falling slightly. Foreigners may threaten trade sanctions if the creditor country in question does not allow its currency to appreciate. ${ }^{6}$ Thus "virtuous" creditor countries become "conflicted".

In what sense are China's huge private sector holdings of liquid dollar assets an overhang? Clearly, if private expectations are such that the exchange rate of yuan remains tightly pegged to the dollar, then existing dollar claims - and further accumulation — can be held in rough portfolio equilibrium. GDP growth and growth in the size of renminbi bank deposits in China have been enormous. Thus Chinese savers could accommodate further parallel growth in their dollar assets. But foreign pressure to appreciate the renminbi has upset what had been a rough portfolio equilibrium. The 2001 to 2005 return flow of previously "flight capital" into China, shown in column 4 of Table 1 by declining cumulative totals of unrecorded capital outflows, could well indicate that private agents were less willing to hold dollar claims. ${ }^{7}$

In order to prevent the renminbi from appreciating, the People's Bank of China (PBC) must intervene in the foreign exchange market to buy the excess dollars. Leaving these interventions

remaining capital controls in order to short the dollar and go long in the renminbi if they thought it might appreciate.

6 Notice that conflicted virtue would not arise in international creditor countries whose money is internationally accepted, as the currency risk is shifted to the periphery. Britain was the world's dominant creditor country in the $19^{\text {th }}$ century, but sterling was used to denominate most British claims on foreigners - sometimes with gold clauses. Similarly, for two and half decades after World War II, the US had large trade surpluses and was the world's biggest creditor country - but its claims on foreigners were largely in dollars and US investors did not have to fear changes in the dollar exchange rate.

7 In 2005-06 higher US interest rates provided a stronger incentive to keep dollar assets rather than convert into yuan. 
(partially) unsterilized ${ }^{8}$ relieves the pressure: the domestic monetary base expands and drives down domestic interest rates relative to those on dollar assets. As long as interest rates on renminbi assets remain well above zero, such increases in the monetary base could be effective in expanding the domestic economy while slowing the growth of official exchange reserves.

Yet, the appreciation threat for China is a repetitive one getting stronger in times of low U.S. interest rates - similar to the earlier Japanese experience with repetitive yen appreciations (McKinnon and Ohno 1997, Schnabl and Baur 2002). As in the Japanese case, China's surplus saving, i.e., its current account surplus, is unlikely to diminish as its currency appreciates. Instead, economic growth would slow and China's price level would start declining. Speculators would understand that China's trade surplus would not diminish and continue to short the dollar and go long in renminbi in anticipation of future pressure from foreigners for appreciation.

Figure 3: Official Foreign Reserves of China and Japan, 1980-2005

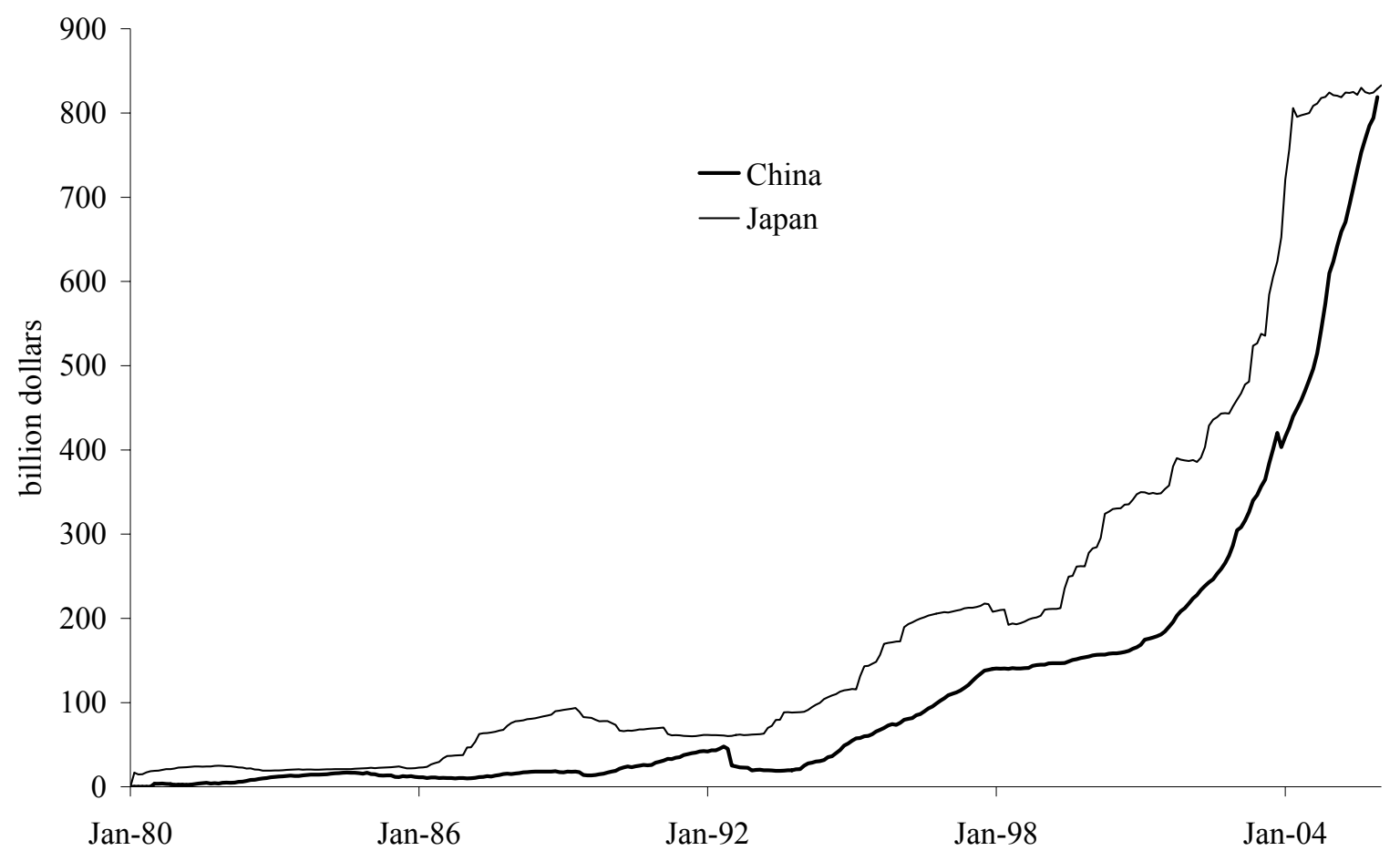

Source: IMF.

8 Since August 2002 when the Peoples Bank of China started sterilization operations by issuing central bank bills, it absorbed more than one third of the liquidity resulting from foreign exchange interventions. Note that under a fixed exchange rate regime (and partial international capital mobility) full sterilization is impossible, as it would drive up interest rates and therefore attract new capital inflows. 
Once the traditional peg is undermined markets would anticipate further appreciations. With no equilibrium upper bound, a floating renminbi could result in an upward spiral (as with the Japanese yen two decades earlier) that would force the PBC back into the market to cap renminbi's dollar value at a higher level. The upshot is that a country with conflicted virtue is trapped and continues to accumulate foreign reserves even above any "desired" level of international liquidity. Since 2001 the stock of Chinese foreign reserves has expanded fast and soon is likely to surpass that of Japan, still largest holder of (dollar) reserves (Figure 3). The upshot is that as long as the center country's price level remains stable, the best a peripheral creditor country can do within the trap is try to limit hot money inflows with capital controls and to keep its nominal (dollar) exchange rate fixed — as China had been doing up to mid 2005.

\subsection{The Negative Risk Premium and Zero-Interest Liquidity Trap}

With conflicted virtue and the expectation of an ever higher renminbi into the indefinite future, nominal interest rates will be bid down. The impact of exchange rate expectations on interest rates gets stronger with the degree to which China's financial system is liberalized. Let's assume that domestic interest rate restrictions are abolished so that domestic bond markets thrive and interest rates on renminbi assets are free to seek their own market-determined level at every term to maturity. Furthermore, we assume that exchange controls on international financial (in)flows are removed so that arbitrage with foreign (dollar based) financial markets is uninhibited. Then it can be assumed that the open interest parity condition links domestic to foreign interest rates to reflect what we call "the negative risk premium" $\varphi$ (Goyal and McKinnon 2003) ${ }^{9}$ :

$$
i=i^{*}+E(\hat{e})+\varphi
$$

where $i$ is the (endogenously determined) Chinese nominal interest rate, and $i^{*}$ is the (exogenously given) U.S. nominal interest rate, and $\mathrm{E}$ the expectations operator. $\hat{e}$ corresponds to

9 Note that the sign of the risk premium is linked to the current account position and the sign of the net international investment position. For countries with sustained current account deficits and a negative net international investment position, the risk premium would be positive. 
the nominal percentage change of the yuan/dollar exchange rate. Thus, if the renminbi is expected to appreciate, $E(\hat{e})<0$.

The risk premium in Chinese interest rates is $\varphi$. Insofar as China's private sector holds dollar assets net, and the yuan/dollar rate would fluctuate, then $\varphi<0$ and we call this the negative risk premium. That is, Chinese wealth holders, whose natural currency habitat is renminbi, see dollar assets to be riskier than renminbi assets even if there is no unidirectional expectation that the renminbi will appreciate. $\varphi$ becomes more negative the more volatile the exchange rate and the greater are private holdings of dollar assets.

Let's first assume that the renminbi could be credibly pegged to the dollar as is almost the case in Hong Kong. Then both $\mathrm{E}(\hat{e})$ and $\varphi$ equal zero and short-term (money market) interest rates in Hong Kong converge towards the U.S. federal funds rate. In contrast, suppose the exchange rate remains fixed but investors face the risk that the renminbi might appreciate. For portfolio equilibrium, the interest rate on renminbi assets must be less that on dollar assets by $|\mathrm{E}(\hat{e})+\varphi|$. The term $|\mathrm{E}(\hat{e})+\varphi|$ reflects the size of any expected discrete appreciation, the probability that it will occur, how distant is the event, and what would be the subsequent turmoil in exchange market fluctuations. Although written in equation (2) simply as an interest rate differential, | $\mathrm{E}(\hat{e})$ $+\varphi \mid$ would be complex to derive algebraically by precisely laying out all of its components.

Because the dollar is the dominant currency in international capital markets (outside of Europe), we assume that the dollar interest rate(s), $i^{*}$, in equation (2), is given exogenously to any portfolio choices made in China. Within China facing the threat that the renminbi might appreciate, the only way the necessary interest differential for securing portfolio balance can be established is for the interest rates on renminbi assets to fall below that on dollar assets. At shorter terms to maturity, the fall in interest rates can be hastened by (partially) unsterilized foreign exchange intervention: as the domestic monetary base increases, short-term rates are bid down. This easy money policy reduces the incentive for financial capital to flow inward, and thus reduces the scale of the intervention necessary to secure the exchange rate. ${ }^{10}$

10 In contrast, sterilized intervention, accompanied by selling central bank bonds, prevents domestic interest rates from falling and so fails to dampen inflows of foreign capital. 
Second, apart from monetary interventions that reduce short-term interest rates, in the absence of capital controls pressure from free international financial arbitrage between dollar bonds and renminbi bonds would nudge down interest rates at longer maturities. Chinese holders of dollar bonds (arising out of the current account surpluses) would sell them off in favor of renminbi bonds until the interest rate on the latter fell below that on the former by the expected appreciation plus the negative risk premium. Of course, the two avenues for putting downward pressure on China's internal interest rates, at different terms to maturity, are intertwined.

The earlier experience of Japan with currency risk from anticipated yen appreciation is instructive. After the mid 1980s, Japan financial markets were more developed and more open to international arbitrage than China's are now. Figure 4 shows Japanese short term (interbank) interest rates falling toward zero in the mid 1990s, and then being stuck at zero from 1999 until the present. On 10-year Japanese Treasury Bonds (JGBs), Figure 5 shows that the yield has been 2 to 5 percentage points below that on 10-year U.S. Treasuries since 1980. In January 2006, the yield on 10-year JGBs was about 1.5 percent while that on 10-year U.S. Treasuries was 4.6 percent. With short-term rates trapped at zero, Japanese monetary policy became helpless to prevent an economic slump or stop deflation. 
Figure 4: Short-Term Interest Rate in the United States, China, and Japan, 1990-2005

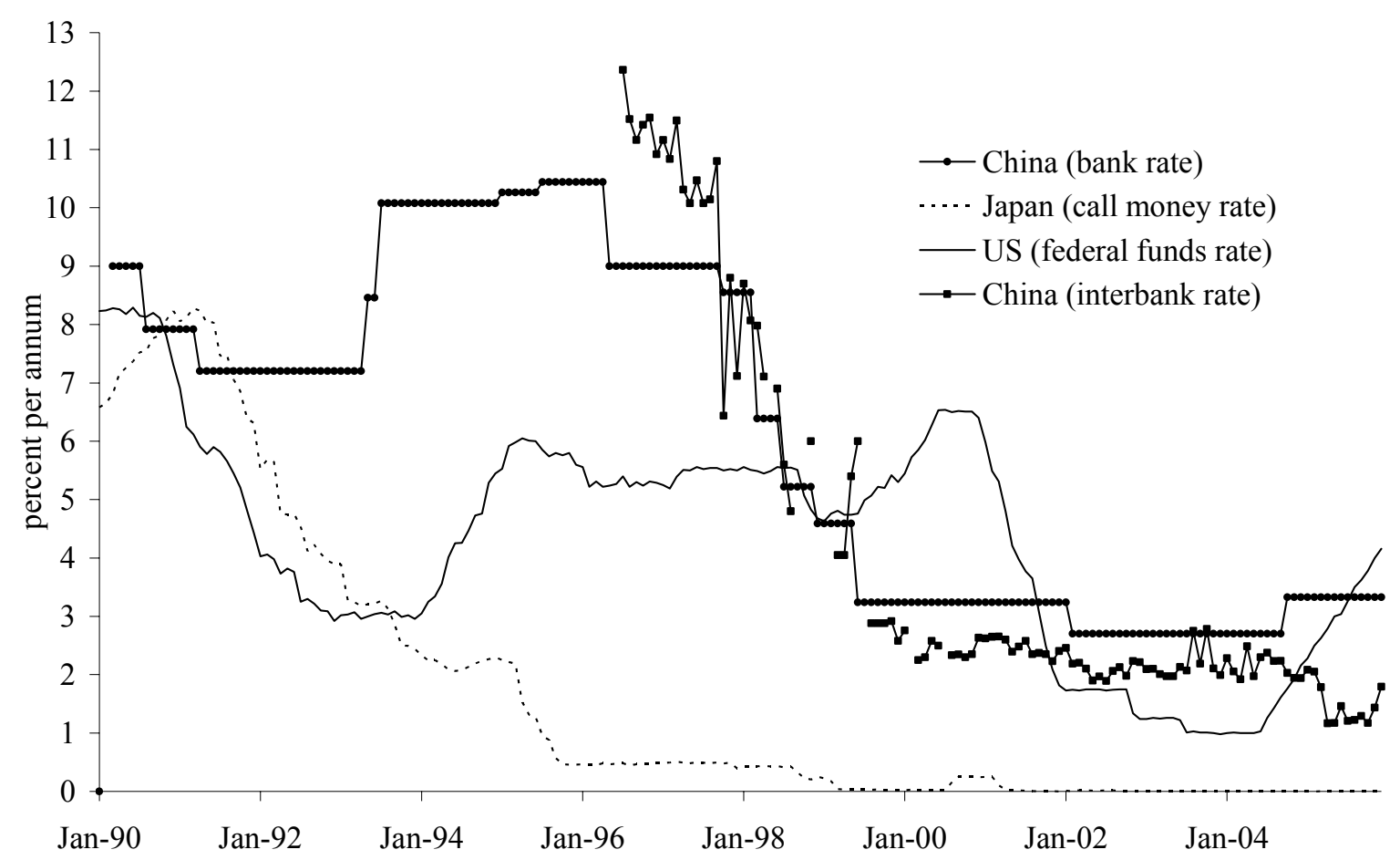

Source: IMF and Bloomberg.

In China today, if financial liberalization proceeds and appreciation expectations become sustained, the probability is high that Chinese interest rates will remain below those in the United States as has been the case since early 2005. As long as U.S. interest rates keep rising, Chinese interest rates are likely to rise as well. If, however, U.S. interest rates again fell, the likelihood increases that China would fall into zero-interest rate liquidity trap. (Since 1999, Japan's shortterm interbank rate has been effectively zero.) China's interbank interest rate is fairly freely determined although the PBC still pegs bank deposit and some loan rates. Figure 4 shows that China's interbank interest rate in early 2006 to be about 1.6 percent even as the U.S. Federal Funds rate (coming off all time lows) rose toward 4.75 percent. 
Figure 5: Long-Term Interest Rates in the United States and Japan, 1980-2005

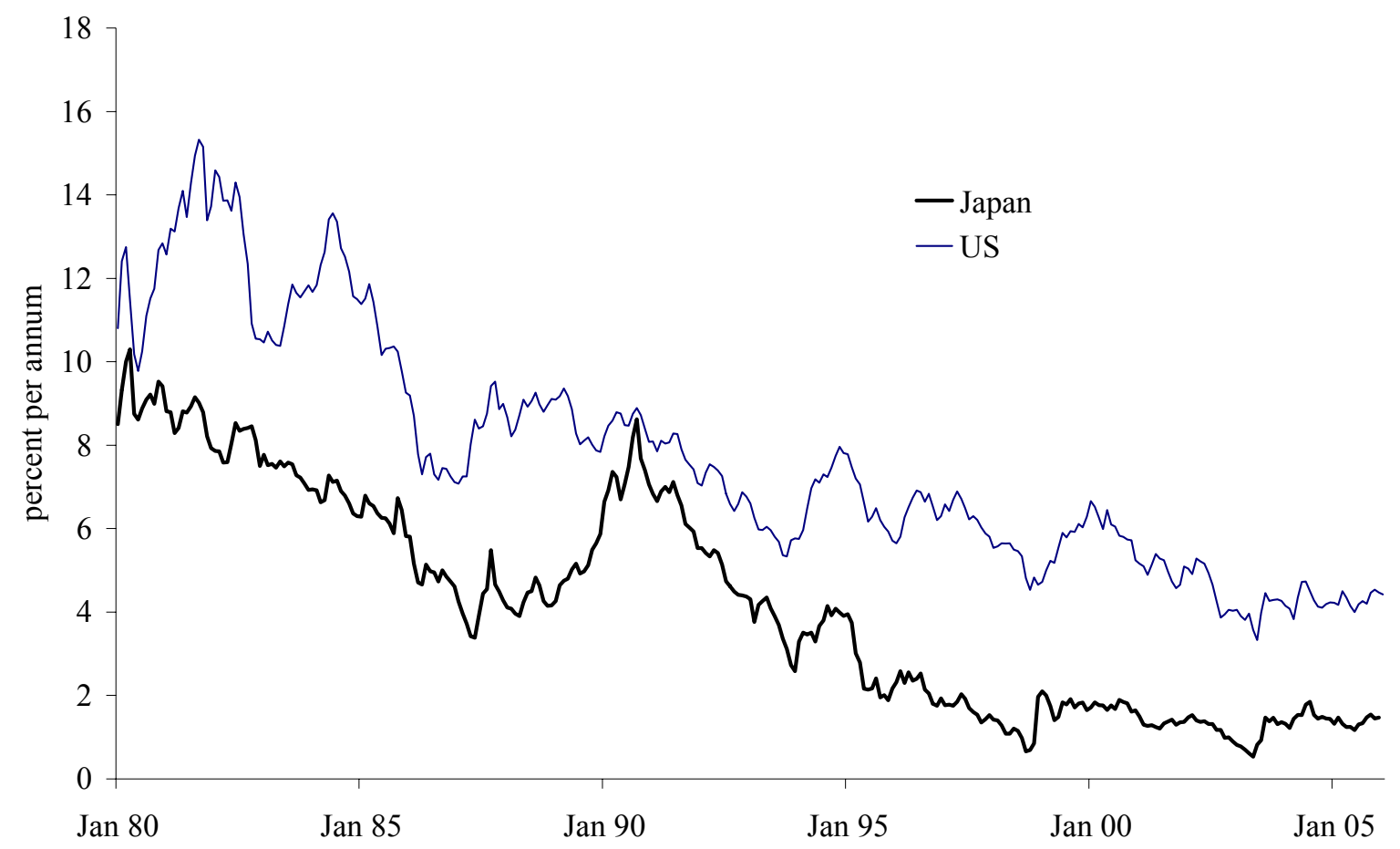

Source: IMF.

Notice that just letting the renminbi float upward, or appreciate discretely, would worsen the dilemma. Actual appreciation would lead to actual deflation with further downward pressure on domestic interest rates. Drawing on Japan's earlier experience of continual yen appreciations, coupled with its erratic fluctuations, we know that interest rates on yen assets were compressed toward zero in the ensuing deflation. The problem of conflicted virtue, trade surpluses financed by accumulating liquid dollar assets, would persist (McKinnon 2005).

\section{Adjustment in Labor Markets}

Despite China's extraordinary growth since 1980 and the large absolute size of its GDP, real output and wages per capita — as well as the overall price level (CPI)—are still much less than in mature industrial economies. Today's huge disparity in the level of money wages between China and the United States reflects the large difference in the average level of labor productivityalthough China is catching up. Balancing international competitiveness requires real wages in China to increase much faster than those in the United States to reflect China's much higher 
growth in labor productivity. What monetary mechanism best promotes and sustains high growth in Chinese wages?

Traditional models of international adjustment such as in Meade (1951) and Friedman (1953) see a flexible exchange rate as a valuable substitute for wage rigidity in the face of externally generated shocks. When nominal wages are rigid, a negative domestic productivity shock or external terms of trade shock warrants offsetting currency depreciation. Real wages are reduced by increasing the domestic prices of tradable goods. Similarly, for countries with positive trade shocks, an appreciation is warranted to balance international competitiveness by increasing effective real wages.

However, this traditional static approach to wage rigidity and the need for exchange rate flexibility in rapidly growing economies is misplaced in two major respects. First, we showed in Section 2 that a discrete appreciation by a creditor economy with conflicted virtue would cause a recession and a decline of imports and therefore has no predictable effects on the trade surplus. Second, for an economy with rapid (labor productivity) growth - as in China today-expected appreciation(s) could depress growth in nominal wages below the natural rate warranted by its high productivity growth in tradable activities. In effect, wages are not rigid in a high growth economy. Whether wages increase at 5 or 15 percent year has a first order impact on wage levels within a fairly short period of time.

In contrast, if the exchange rate is safely fixed, wage growth, if not the wage level, can be highly responsive to varying rates of labor productivity growth so as to better balance international competitiveness. Based on the "Scandinavian Model" of wage adjustment, we show that fixing the nominal exchange rate to a stable external monetary anchor facilitates faster adjustment (growth) in real wages than leaving the exchange rate "flexible" with the threat of appreciation.

\subsection{The Scandinavian Model of Wage Adjustment}

In a "small" open economy with high productivity growth, the evolution of domestic wages and prices under alternative exchange rate regimes can be described by the Scandinavian Model of wage adjustment. Under the Bretton Woods System of fixed dollar parities, Sweden along with 
Norway and Denmark, were among Western Europe's fastest growing economies. The writings of several earlier Scandinavian authors were summarized by Lindbeck (1979) with the simple equation system developed below. ${ }^{11}$

The first assumption of the Scandinavian Model is that relative purchasing power parity holds for tradable goods: domestic price inflation in tradables converges to the world (dollar) rate of inflation plus the rate of currency depreciation $\hat{e}$.

$\hat{p}_{T}^{A}=\hat{p}_{T}^{W}+\hat{e}$

Where $\hat{p}_{T}^{A}$ is inflation in tradable goods prices of country A and $\hat{p}_{T}^{W}$ is "world" price inflation measured in terms of the world's dominant money, which was (and is) the dollar. As the Scandinavian authors were writing in the 1960s when dollar exchange rates were tightly fixed under the Bretton Woods Agreement, ${ }^{12}$ we assume the exchange rate is credibly fixed $(\hat{\mathrm{e}}=0)$. Given stable exchange rates, arbitrage in international markets for tradable goods is sufficiently robust that inflation in the traded goods sector of country A converges to inflation in the dollar prices of traded goods on world markets.

Lindbeck (1979) further assumed that wage bargaining (in the Swedish economy) was initiated in the tradable goods sector where labor productivity grew faster, particularly in manufacturing, than in non-tradables that were largely services. Let $\hat{q}_{T}^{A}$ represent the growth of labor productivity in tradables as if the economy had only one factor of production. This productivity growth reflects increasing stocks of human and physical capital that are not being explicitly modelled. The mighty Swedish trade unions were able to capture these productivity gains for both skilled and unskilled labor so that

$\hat{w}_{T}^{A}=\hat{p}_{T}^{A}+\hat{q}_{T}^{A}$

11 The Scandinavian model can also an be seen as an time-series extension of the Balassa-Samuelson model (Balassa 1964, Samuelson 1964). 
where $\hat{w}_{T}^{A}$ is the average rate of the increase in nominal money wages paid to workers in the open, or what the Swedes called the "unsheltered", tradables sector.

This wage bargaining was constrained by the fixed exchange rate. If unions bargained for nominal wage increases greater than shown in (4), they risked making Swedish industry uncompetitive in world markets with a fall in employment. Thus (4) defines the natural rate of increase nominal wages in an open economy. As long as inflation in world prices, $\hat{p}_{T}^{W}$, remains low and fairly predictable, ${ }^{13}$ workers are content to bargain in money terms reflecting concurrent trends in productivity growth and in inflation. That is, there is no formal indexing of real wage levels or wage growth, nor any attempt to adjust for anticipated changes in the exchange rate.

In a more competitive labor market, such as that in high-growth modern China discussed below, unions are not important. However, employers are willing to bid aggressively for workersparticularly skilled or semi-skilled—so that the average wage for these heterogeneous workers increases according to (4), still reflecting the fixed exchange rate constraint. In part, $\hat{w}_{T}^{A}$, reflects a return to workers' increasing skills from on-the-job training and education—as well as a rising marginal product of labor from capital deepening.

Labour "solidarity" as well as the mobility of labor between the manufacturing sector and the non-tradable (NT) sectors of the economy transmits the manufacturing wage increases $\left(\hat{w}_{T}^{A}\right)$ to wage increases in the non-tradable sectors $\left(\hat{w}_{N T}^{A}\right)$. As the non-tradable sectors were widely shielded from world markets, prices in these sectors would not be driven by international competition but would be based on domestic labor costs. Because the productivity increases in the non-tradable (service) sector were assumed to have been smaller than in the manufacturing sector, the price increases $\left(\hat{p}_{N T}^{A}\right)$ in the non-tradable sector tend to be driven by wage increases $\left(\hat{w}_{N T}^{A}\right)$ minus the productivity gains in the non-traded goods sector $\left(\hat{q}_{N T}^{A}\right)$ :

12 One of the big surprises of the era of fluctuating exchange rates after 1971 was the persistent deviations from (relative) purchasing power once exchange rates were no longer tethered.

13 The US wholesale price level, "the world's nominal anchor for tradable goods" was remarkably stable in the 1950 s to the late 1960s, the period in which the Scandinavian Model was developed. Then, in the 1970s and 1980 s, there was turmoil from high inflation and painful disinflation. But stability was regained in the 1990s. 
$\hat{p}_{N T}^{A}=\hat{w}_{N T}^{A}-\hat{q}_{N T}^{A}$ with $\hat{q}_{N T}^{A}<\hat{q}_{T}^{A}$

The equations (2), (4) and (5) yield equation (6) that shows the impact of world market prices, exchange rate changes, and relative sectoral productivity gains, on non-traded goods prices. Note that the differential in productivity increases between the traded and non-traded goods sectors contributes to inflation and that, under the Bretton Woods system, exchange rates were fixed so that $\hat{e}=0$ :

$\hat{p}_{N T}^{A}=\hat{p}_{T}^{W}+\hat{e}+\hat{q}_{T}^{A}-\hat{q}_{N T}^{A}$ with $\hat{e}=0$

In the Scandinavian model, the wage bargaining and price adjustment process in the traded and non-traded goods sectors would affect general inflation $\left(\hat{p}^{A}\right)$, which is defined as a composite of traded goods price inflation and non-traded goods price inflation given the respective weights $\alpha$ and $(1-\alpha)$ :

$$
\hat{p}^{A}=\alpha \hat{p}_{T}^{A}+(1-\alpha) \hat{p}_{N T}^{A}
$$

Equations (1), (6) and (7) yield equation (8) which can be interpreted as a measure for supply driven inflation:

$\hat{p}^{A}=\left(p_{T}^{W}+\hat{e}\right)+(1-\alpha)\left(\hat{q}_{T}^{A}-\hat{q}_{N T}^{A}\right)$

In equation (8) the term $p_{T}^{W}+\hat{e}$ is equivalent to imported inflation. If world market prices in the traded goods sector rise and or the exchange rate depreciates (exchange rate induced inflation) this would fuel into inflation. The term $\hat{q}_{T}^{A}-\hat{q}_{N T}^{A}$ describes the structural component of CPI inflation which is mainly in line with Balassa-Samuelson effect of supply driven inflation (Balassa 1964 and Samuelson 1964). Higher productivity gains in the traded goods sector-both higher than in the non-traded goods sector and higher than abroad - are translated via the wage bargaining process into higher CPI inflation. The larger the weight of the non-tradable goods 
sector, the larger is the impact of the Balassa-Samuelson effect on inflation. Even if the exchange rate is fixed, inflation can differ among countries due to different productivity growth. The money supply is endogenous and national monetary policy is geared to maintaining the fixed exchange rate.

The upshot is that, within the Scandinavian model of wage adjustment, the bidding of trade unions for higher wages is constrained by the fixed exchange rate. Trade unions could reap the full benefits of productivity gains and equilibrate the international competitiveness between Sweden and the United States. The trade unions would, however, not want to ask for wage increases above the domestic productivity gains as this would damage the country's international competitiveness. Thus, the peg to the dollar provided a welfare enhancing environment for wage adjustment during the economic catch-up process.

\subsection{The Japanese Experience}

In order to better understand if international competitiveness is better balanced when the nominal exchange rate is fixed rather than fluctuating, Japan provides a useful case study. When the yen was fixed at 360 to the dollar from 1950 to 1971, the importance of relative wage adjustment between Japan and the United States was pronounced. Driven by the faster growth of productivity in the Japanese manufacturing sector, both wages and consumer prices grew substantially faster than in the U.S. as shown in Figure 6. Money wages as balancing item of international competitiveness grew at a rate of 10 percent per year in Japan and only 4.5 percent in the U.S. Keeping the yen at 360 per dollar anchored Japan's price level for tradable goods as Japanese wholesale prices rose at about the same speed as U.S. wholesale prices. Because the bulk of world trade was invoiced in dollars, fixing the exchange rate to the dollar was (is) a stronger anchor for the price level than the size of Japanese bilateral trade with the United States would suggest. 
Figure 6: Inflation and Wage Differentials between Japan and US, 1950-2005

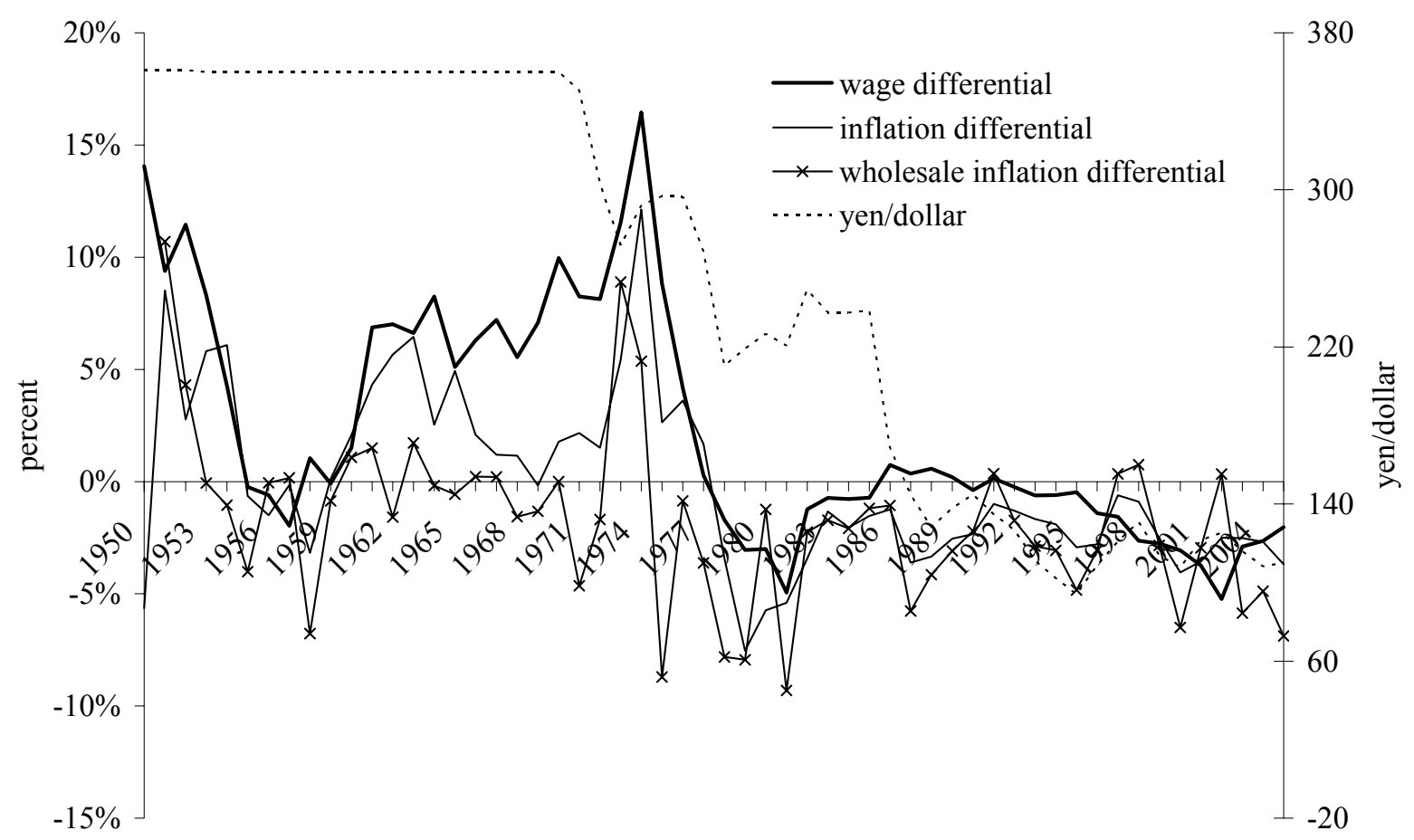

Source: IMF. Positive values indicate higher inflation and higher wage increases in Japan.

Employers in Japan's manufacturing export sector, with its extremely high growth in labor productivity, then bid vigorously for both skilled and unskilled workers subject to remaining internationally competitive at the fixed exchange rate. ${ }^{14}$ Wages rose rapidly in manufacturing so that workers received the main fruits from the productivity growth there. But then, as in the Scandinavian Model, these high wage settlements spread into the rest of the economy, such as nontradable services, where productivity growth was much lower. The result was that, within Japan, the price of services rose relative to goods prices. For 1950-71, Japan's CPI, which includes services as well as goods, increased at about 5 percentage points faster per year than its wholesale price index (which contains only goods) and faster than the U.S. CPI. However, Japan's international competitiveness in its high-growth tradables sector remained balanced with the United States.

\footnotetext{
${ }^{14}$ Note that in contrast to China the supply of labor in Japan is traditionally limited.
} 
In Japan's bygone high-growth era, finding a purely domestic monetary anchor would have been more difficult. As in China today, restrictions on domestic interest rates proliferated; and the rate of growth in narrow money was high and unpredictable as Japanese households rebuilt their financial assets after the war. Thus having the Bank of Japan simply key on the dollar exchange rate was the most convenient instrument for stabilizing Japan's tradable goods price level while promoting high growth in money wages.

By the end of the 1960s, however, American monetary policy became too inflationary and the Bretton-Woods-System collapsed. For two decades after August 1971 up to the late 1980s, productivity growth in Japan remained high relative to that in the United States. Japanese exports made major inroads into American markets, the U.S.-Japanese trade imbalance emerged and the U.S. government reacted by continually trying to "talk" or force the yen up on the presumption that an appreciating yen would improve America's external competitiveness (McKinnon and Ohno 1997, chapter 5). Indeed, the yen did rise all the way from 360 in 1971 to 80 to the dollar in April 1995, and threw Japan into its deflationary slump of the 1990s with a zero interest liquidity trap that lasts to the present day (McKinnon 2005).

The deflation reduced growth in Japanese money wages and relative wage adjustment broke down - albeit with a lag. Before 1975, money wage growth in Japan remained much higher than in the United States. Subsequently, as relative deflation in Japan set in, Japan's money wage growth slowed sharply-the bold line in Figure 6. From the 1980s into the new millennium, wage growth in Japan became even lower than that in the United States. So, besides damaging the Japanese economy in a macroeconomic sense while failing to reduce its trade surplus, the erratically appreciating yen undermined the natural process of relative wage adjustment for balancing international competitiveness.

The changes in the wage adjustment mechanism are also related to Japanese monetary policy, which became less predictable as the monetary policy target tended to "switch" between domestic inflation and the exchange rate (Schnabl and Danne 2005). In times of when the yen was weaker in the foreign exchanges, monetary policy decision making focused on the domestic marketsimilar to the U.S. and (by then) Germany. However, when the yen was appreciating, the Japanese monetary authorities were unable to neglect targeting the exchange rate (McKinnon and 
Ohno 1997). The successive attempts to stop appreciation by foreign exchange intervention led to the buildup of the world largest stock of foreign reserves (Figure 3)-although perhaps soon to be overtaken by China's — and the world's lowest interest rate level.

\subsection{Wage Adjustment in China under a Fixed Exchange Rate}

Unlike Japan after 1971, China has kept its exchange rate stable since 1994 up to July 2005. Since then it has allowed only for very little appreciation of the Chinese currency keeping it tightly pegged to the dollar. As shown in Figure 7, fixing the exchange rate against the dollar helped stabilize inflation. Before 1996, Chinese CPI inflation was high and volatile, but then declined as it converged close to the U.S. level. Because of a potential Balassa-Samuelson effect, however, one might expect "equilibrium" inflation in high-growth China to be greater than that in the U.S.. Apparently, because of high productivity growth in China's nontradable sectors, the Balassa-Samuelson effect is muted compared to Japan's earlier experience with a rising CPI. Thus the small differential in CPI inflation rates between the two countries can be seen as an equilibrium in the sense of the relative purchasing power parity as per equation (3).

In addition Figure 8 shows that (together with the rising degree of economic openness) the volatility of inflation was accompanied by a more stable growth path. While before 1994 real growth rates fluctuated strongly, after 1994 they stabilized around a level of approximately 9 percent. Figure 8 is consistent with the hypothesis that a nominal exchange rate peg provides a stable framework for price and wage adjustment during the economic catch-up process. 
Figure 7: Yuan/Dollar Exchange Rate and CPI Inflation Differential, 1990 - 2005

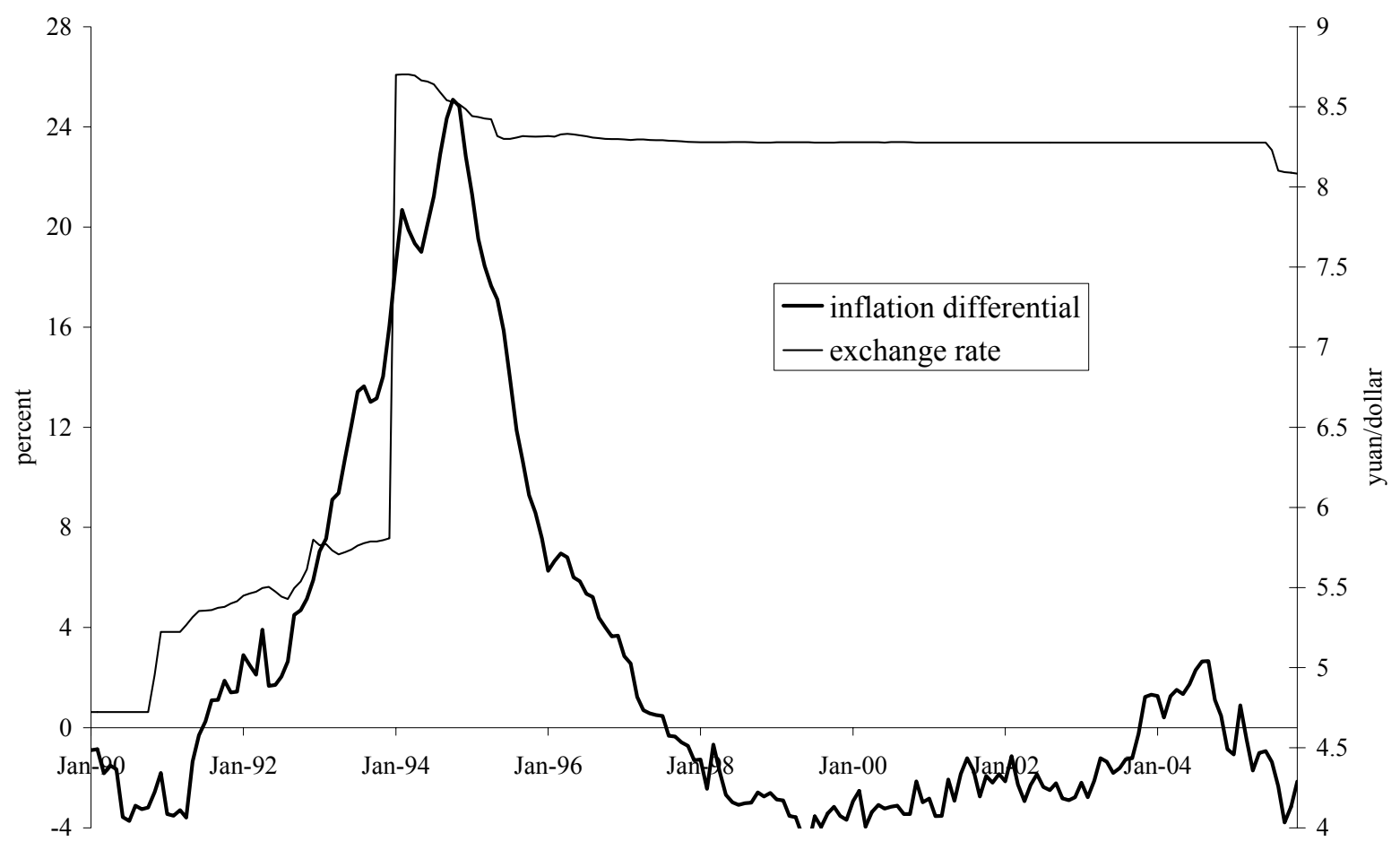

Source: IMF. Positive values indicate higher inflation in China.

Figure 8: Real Growth and Inflation in China, 1980-2005

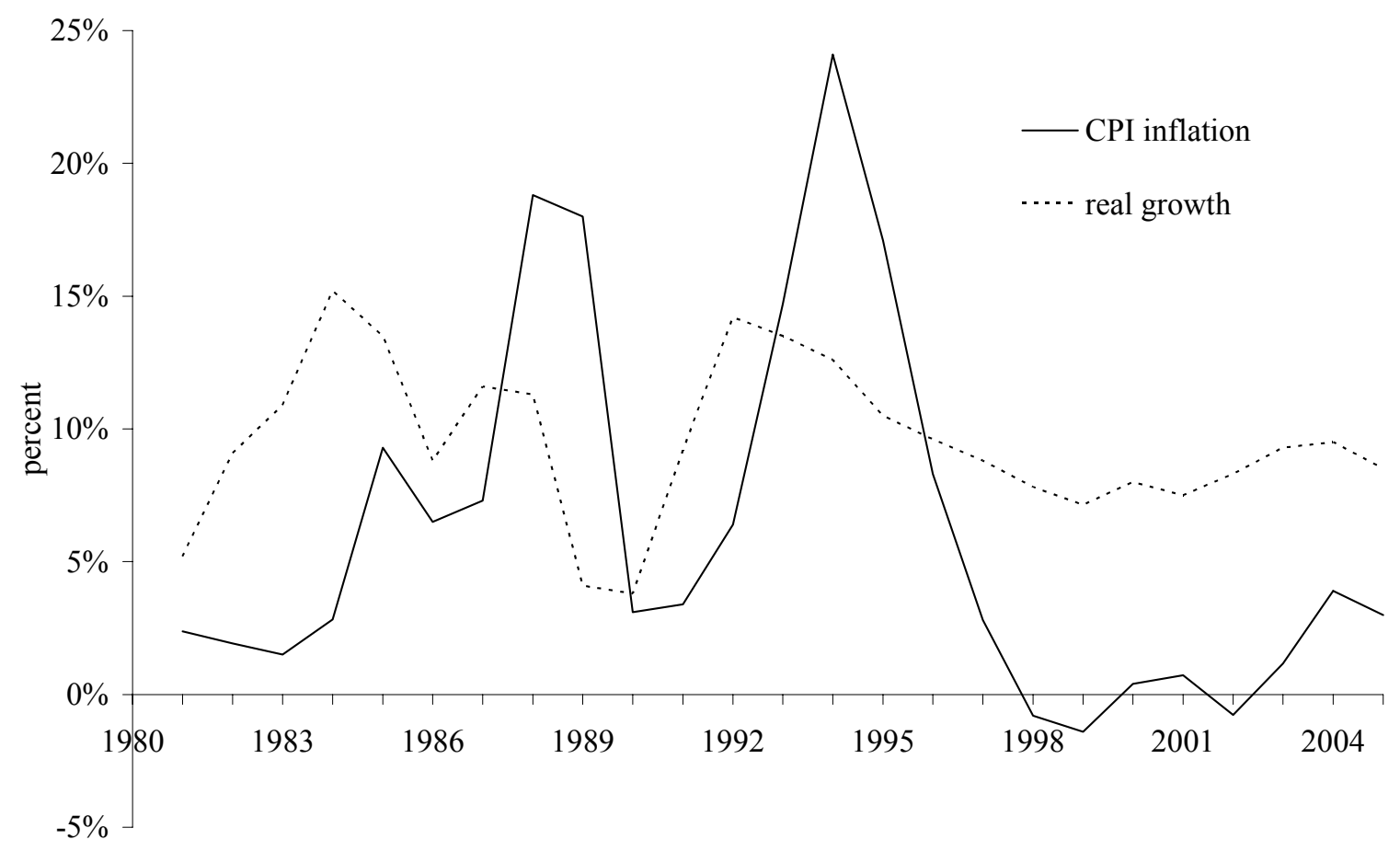

Source: IMF. 
How did China's dollar peg effect the wage bargaining process? Although productivity growth in China remains difficult to measure, it is undisputed that over the past decade Chinese productivity growth was substantially larger than in the U.S. Zhang and Tan (2004) estimate Chinese annual labor productivity growth to be 12.32 percent between 1994 and 2001. Our estimate based on real value added in manufacturing since 1994 suggests that Chinese productivity grew by 9.5 percent. In contrast, U.S. labor productivity grew by about by 3 percent during the same time period. To preserve the exchange rate anchor and to balance international competitiveness, nominal wages had to grow in line with the rapid productivity growth and thereby much faster than in the U.S. Figure 9 shows the wage growth in the Chinese economy across different sectors has been much faster than average wage growth in the U.S. Between 1995 and 2005 nominal wages in Chinese urban areas grew by about 11 percent per year, while U.S. wages grew by about 3 percent.

Figure 9: China: Nominal Wage Increases across Different Sectors in Comparison to the US Overall Nominal Wage Increases, 1994-2004

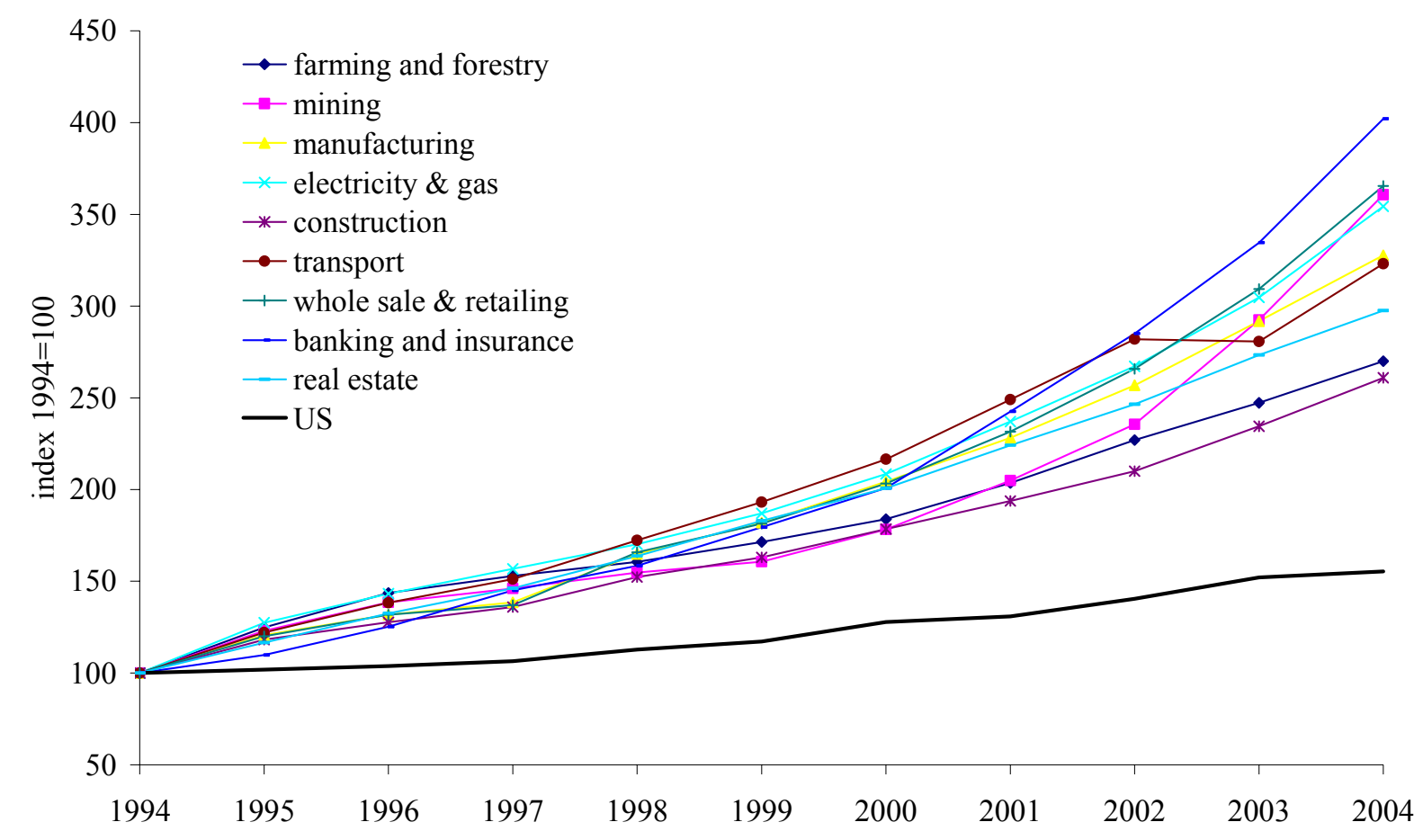

Source: IMF, CEIC Database.

Much of this extraordinary increase of Chinese nominal wages reflects the upgrading of skills in the Chinese manufacturing sector and elsewhere (Figure 9). The wage growth of unskilled 
migrant workers from rural areas is likely to lag behind, and many of these workers are absorbed by the construction industry where wage growth is slowest among all the sectors. However, Figure 9 shows a remarkable tendency for Chinese money wage growth to be high across all sectors during the decade of fixed exchange rates from 1994 to 2004.

Figure 10: China and US: Exchange Rate, Inflation and Wage Growth Differential, 19902005

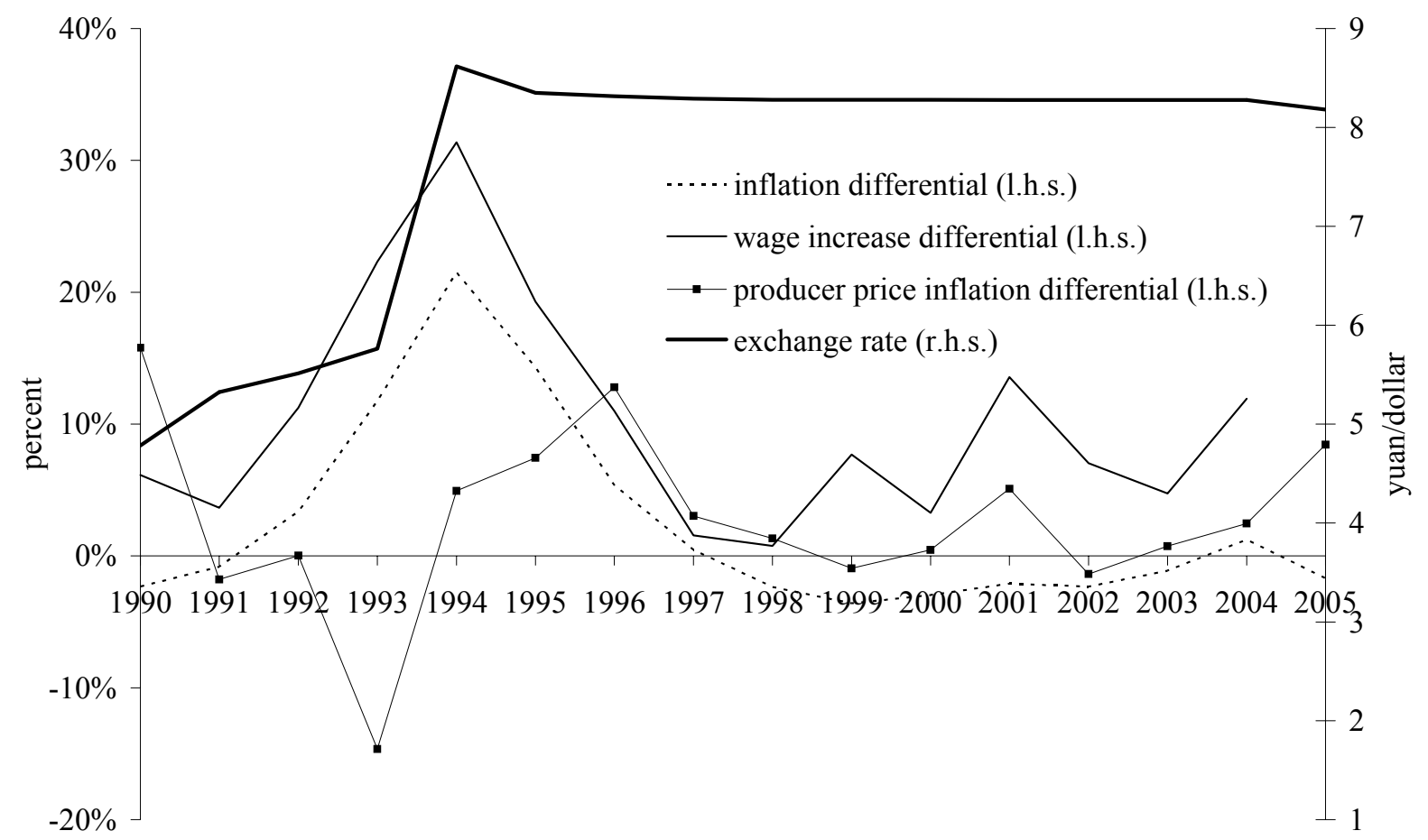

Source: IMF and CEIC Database. Positive values indicate higher inflation and higher wage increases in China.

Remembering that the data are imperfect, Figure 10 for China-which is the equivalent to Figure 6 for Japan - shows the exchange rate of the yuan against the dollar as well as the differences in wage growth and CPI inflation. Under the fixed exchange rate regime, China's international competitiveness seems to be balanced as the Scandinavian model would suggest it. At fixed exchange rates, wage growth has been substantially higher than in the U.S. reflecting the China's higher productivity growth. In contrast to the earlier experience of Japan, consumer price inflation in China has become similar to that in the U.S. The Balassa-Samuelson effect in China has been quite limited perhaps because China is a more open economy than Japan was with lots 
of foreign direct investment into service activities enhancing productivity growth. ${ }^{15}$ But like in Japan under the Bretton-Woods-System, China's fixed exchange rate from 1994-2005 provided a stable framework for wage adjustment in the economic catch-up process.

\subsection{Wage Adjustment with Threatened Currency Appreciation}

Now assume that China opts for more exchange rate flexibility, as it seemed to do on July 21, 2005 , that is likely to lead to the expectation of further appreciations. Because the future exchange rate is now uncertain, risk-averse employers in the export sector face greater uncertainty in wage bargaining in bidding for workers. To negotiate the appropriate wage today, they have to guess how much exchange appreciation will occur in the future. Chinese export enterprises could suffer losses and possible bankruptcy if they bid up wages too strongly and find that the yuan has appreciated more than expected. Let us call this additional uncertainty the negative risk premium in wage bargaining $\psi$ (with $\psi<0$ ). Assuming for simplicity that inflation is close to zero (as it was in 2005 in China), then:

$$
\hat{w}^{A}=E\left(\hat{q}_{T}^{A}\right)+E(\hat{e})+\psi
$$

The desired growth in nominal wages of (skilled) Chinese workers $\hat{w}^{A}$ is equivalent to expected productivity growth $\left(E\left(\hat{q}_{T}^{A}\right)>0\right)$ minus expected appreciation $(E(\hat{\mathrm{e}})<0)$, and minus the risk premium in the wage bargaining process. $\psi$ becomes larger (more negative) when expected future volatility in exchange rates increases. If the exchange rate of the yuan would stay tightly pegged to the dollar, both the expected mean appreciation and the wage risk premium $\psi$ would be zero. Nominal wage growth would then accurately reflect the ongoing growth in real labor productivity.

However, suppose instead that the exchange rate is expected to appreciate along some well known pre-determined path—say 3 percent per year. That is, the degree of appreciation is certain.

\footnotetext{
${ }^{15}$ Zhang (2003) argues that excessive market entry has consumer prices held low.
} 
Then the risk premium $\psi$ would be zero, and nominal wage would grow at the same rate as productivity minus the expected appreciation. On a balanced deflation path (falling price level) corresponding to a known rate of currency appreciation, real wages would still grow in line productivity.

Now suppose that the degree of appreciation is uncertain - as it has been and is the case for Japan, and is the case for China under more flexible rates since July 2005. Then real wages would grow less than productivity because the negative wage risk premium is higher than under a stable exchange rate regime. That is, there could be a shortfall in real wage growth that, paradoxically, makes the economy even more competitive internationally. But how this works itself out, with all the various lags involved, would require a more complete macroeconomic model than that presented here

We know from Japan, that, after 1974, nominal wage growth slumped significantly and wages started to grow slower than in the U.S. (Figure 6). The erratically appreciating yen undermined the process of relative wage adjustment for balancing international competitiveness between Japan and the U.S.

\section{A Concluding Note on the Problem of Monetary Control}

For countries in the economic catch-up process with underdeveloped capital markets foreign exchange risk constitutes a much larger problem than for the highly developed United States or euro area. Both underdeveloped capital markets and a sustained (real) appreciation pressure due to relative productivity gains can lead to micro and macroeconomic instability as the exchange rate fluctuates.

First, we have shown that a fixed exchange rate against the dollar ensures asset market equilibrium between the creditor country China and the debtor country United States. By credibly fixing the exchange rate, deflationary pressure and the fall into a zero interest rate liquidity trap is circumvented. A detrimental stop-and-go in monetary policy is avoided, which further contributes to a stable growth performance. Second, in labor markets, uncertainty is reduced 
under fixed exchange rates because trade unions and enterprises can more easily keep wage settlements in line with productivity growth. To this end, China might do well to keep its exchange rate tightly pegged to the dollar as long as its economic catch-up path continues and capital markets remain underdeveloped.

However, pegging to the dollar means that the national monetary policy in the peripheral country must, in the not-so-long run, be subordinated to maintaining the exchange rate. The rate of national money growth becomes endogenous. When the economy is growing very fast, say near 10 percent per year as in China, and the desired build up of financial wealth by Chinese is even higher (reflecting China's incredibly high saving rate), the demand for base money may well grow at 16-17 percent per year and still be consistent with a stable price level. Such high money growth rates were observed in Japan in the 1950s and 1960s and in China in the last decade.

But on the supply side in the Chinese case, we know that large current account and FDI surpluses in the presence of conflicted virtue leads to a huge build up of official exchange reserves. And when the Peoples Bank of China (PBC) enters the foreign exchange market to prevent the renminbi from appreciating by buying dollars and selling renminbi, the initial effect is to expand the monetary base correspondingly. Only by accident would such a monetary expansion exactly match the increased demand for base money, the growth in which is still so large as to soak up most of the increased supply—at least in non-crisis periods.

If new supplies of base money coming through the foreign exchanges are insufficient to accommodate the rising demand for it, the PBC would have to use discounting or domestic openmarket operations to expand the monetary base further. However, if the creation of base money coming through the foreign exchanges is even greater than the rapid increase in demand (as seems to be the case at present), then the excess money issue has to be sterilized one way or another. The PBC has been issuing its own central bank bonds to mop up much of the excess liquidity —and, in more intense crisis periods, may actually increase bank reserve requirements as well as imposing lending constraints on the banks.

Central bank bonds may be soaking up on average about one third or higher of new base money creation coming through the foreign exchanges. Can this go on indefinitely? Yes, because of the 
very low interest rates on renminbi assets arising out of expected appreciation plus the negative interest rate risk premium. Like the Bank of Japan, the PBC makes a profit out of its foreign exchange operations. The PBC sells central bank yuan-denominated bonds to the good burghers of Shanghai ${ }^{16}$ while buying much higher-yield dollar bonds. (If the risk premium was positive rather than negative, then the fiscal cost of such sterilization operations would be considerable as in, say, Brazil.)

Thus, the governors of the PBC can indeed control money growth to be consistent with a stable price level and a fixed exchange rate-whose strength or weakness (in a country with underdeveloped capital markets) is valuable information on whether monetary liquidity is too scarce or too plentiful. Of course, this regime becomes more complex to administer once the currency begins to appreciate erratically. All in all, we should note that the extremely high money growth rates in China are an equilibrium phenomenon and not an indication of inflation to come. The threat is one of future deflation should the renminbi continue to appreciate.

\section{References}

Balassa, Bela 1964: The Purchasing-Power Parity Doctrine: A Reappraisal. Journal of Political Economy 6, 584-566.

Bernanke, Ben 2005: The Global Saving Glut and the US Current Account Deficit. Sandridge Lecture, Virginia Association of Economics, Richmond Virginia.

Cline, William 2005: The United States as a Debtor Nation. Washington D.C.: Institute for International Economics.

Frankel, Jeffrey 2006: On the Yuan. The Choice between Adjustment under a Fixed Exchange Rate and a Flexible Exchange Rate. Mimeo.

Friedman, Milton 1953: The Case of Flexible Exchange Rates. In Friedman, Milton: Essays in Positive Economics, Chicago.

Goldstein, Morris 2003: China's Exchange Rate Regime. Testimony before the Subcommittee on Domestic and International Monetary Policy, Trade, and Technology Committee on Financial Services. US House of Representatives, October 1, 2003.

Goyal, Rishi / McKinnon, Ronald 2003: Japan's Negative Risk Premium in Interest Rates: The Liquidity Trap and Fall in Bank Lending. The World Economy 26, 3, 339-363.

Lindbeck, Assar 1979: Inflation and Unemployment in Open Economies, Amsterdam, North Holland.

McKinnon, Ronald / Ohno, Kenichi 1997: Dollar and Yen. Resolving Economic Conflict between the United States and Japan, Cambridge (Massachusetts).

\footnotetext{
${ }^{16}$ We are indebted to Gerhard Illing for this felicitous phrase
} 
McKinnon, Ronald (2005): Exchange Rates under the East Asian Dollar Standard: Living with Conflicted Virtue . MIT Press.

McKinnon, Ronald / Schnabl, Gunther 2004a: The East Asian Dollar Standard, Fear of Floating, and Original Sin. Review of Development Economics 8 (2004), 3, 331-360.

McKinnon, Ronald / Schnabl, Gunther 2004b: A Return to Exchange Rate Stability in East Asia? Mitigating Conflicted Virtue. International Finance 7 (2004), 2, 169-201.

McKinnon, Ronald / Schnabl, Gunther 2006: Devaluing the Dollar: A Critical Analysis of William Cline's Case for a New Plaza Agreement. Mimeo.

Meade, James 1951: The Balance of Payments. London

Qiao, Hong 2005: Exchange Rates and Trade Balance under the Dollar Standard. Stanford University, Center for International Development, China Working Paper Series \#259

Samuelson, Paul 1964: Theoretical Notes on Trade Problems. Review of Economics and Statistics 64, 145-154.

Schnabl, Gunther 2000: Leistungsbilanz und Wirtschaftspolitik: das Beispiel Japan. BadenBaden.

Schnabl, Gunther / Baur, Dirk 2002. Purchasing Power Parity: Granger Causality Tests for the Yen-Dollar Exchange Rate. Japan and the World Economy 14, 4, 425-444.

Schnabl, Gunther / Danne, Christian 2005: The Changing Role of the Yen/Dollar Exchange Rate for Japanese Monetary Policy. Tübinger Diskussionsbeitrag No. 290.

Zang, Xiabao / Tan, Kong-Yam 2004: Blunt to Sharpened Razor: Incremental Reform and Distortion in the Product and Capital Markets in China. International Food Policy Research Institute DSGD Discussion Paper 13.

Zhang, Jun 2003: China's Industrial Reform and Economic Growth [In Chinese with English Summary]. Shanghai. 


\title{
CESifo Working Paper Series
}

\author{
(for full list see www.cesifo-group.de)
}

1657 Daniel Haile, Abdolkarim Sadrieh and Harrie A. A. Verbon, Cross-Racial Envy and Underinvestment in South Africa, February 2006

1658 Frode Meland and Odd Rune Straume, Outsourcing in Contests, February 2006

1659 M. Hashem Pesaran and Ron Smith, Macroeconometric Modelling with a Global Perspective, February 2006

1660 Alexander F. Wagner and Friedrich Schneider, Satisfaction with Democracy and the Environment in Western Europe - a Panel Analysis, February 2006

1661 Ben J. Heijdra and Jenny E. Ligthart, Fiscal Policy, Monopolistic Competition, and Finite Lives, February 2006

1662 Ludger Woessmann, Public-Private Partnership and Schooling Outcomes across Countries, February 2006

1663 Topi Miettinen and Panu Poutvaara, Political Parties and Network Formation, February 2006

1664 Alessandro Cigno and Annalisa Luporini, Optimal Policy Towards Families with Different Amounts of Social Capital, in the Presence of Asymmetric Information and Stochastic Fertility, February 2006

1665 Samuel Muehlemann and Stefan C. Wolter, Regional Effects on Employer Provided Training: Evidence from Apprenticeship Training in Switzerland, February 2006

1666 Laszlo Goerke, Bureaucratic Corruption and Profit Tax Evasion, February 2006

1667 Ivo J. M. Arnold and Jan J. G. Lemmen, Inflation Expectations and Inflation Uncertainty in the Eurozone: Evidence from Survey Data, February 2006

1668 Hans Gersbach and Hans Haller, Voice and Bargaining Power, February 2006

1669 Françoise Forges and Frédéric Koessler, Long Persuasion Games, February 2006

1670 Florian Englmaier and Markus Reisinger, Information, Coordination, and the Industrialization of Countries, February 2006

1671 Hendrik Hakenes and Andreas Irmen, Something out of Nothing? Neoclassical Growth and the 'Trivial' Steady State, February 2006

1672 Torsten Persson and Guido Tabellini, Democracy and Development: The Devil in the Details, February 2006 
1673 Michael Rauber and Heinrich W. Ursprung, Evaluation of Researchers: A Life Cycle Analysis of German Academic Economists, February 2006

1674 Ernesto Reuben and Frans van Winden, Reciprocity and Emotions when Reciprocators Know each other, February 2006

1675 Assar Lindbeck and Mats Persson, A Model of Income Insurance and Social Norms, February 2006

1676 Horst Raff, Michael Ryan and Frank Staehler, Asset Ownership and Foreign-Market Entry, February 2006

1677 Miguel Portela, Rob Alessie and Coen Teulings, Measurement Error in Education and Growth Regressions, February 2006

1678 Andreas Haufler, Alexander Klemm and Guttorm Schjelderup, Globalisation and the Mix of Wage and Profit Taxes, February 2006

1679 Kurt R. Brekke and Lars Sørgard, Public versus Private Health Care in a National Health Service, March 2006

1680 Dominik Grafenhofer, Christian Jaag, Christian Keuschnigg and Mirela Keuschnigg, Probabilistic Aging, March 2006

1681 Wladimir Raymond, Pierre Mohnen, Franz Palm and Sybrand Schim van der Loeff, Persistence of Innovation in Dutch Manufacturing: Is it Spurious?, March 2006

1682 Andrea Colciago, V. Anton Muscatelli, Tiziano Ropele and Patrizio Tirelli, The Role of Fiscal Policy in a Monetary Union: Are National Automatic Stabilizers Effective?, March 2006

1683 Mario Jametti and Thomas von Ungern-Sternberg, Risk Selection in Natural Disaster Insurance - the Case of France, March 2006

1684 Ken Sennewald and Klaus Waelde, "Itô's Lemma“ and the Bellman Equation for Poisson Processes: An Applied View, March 2006

1685 Ernesto Reuben and Frans van Winden, Negative Reciprocity and the Interaction of Emotions and Fairness Norms, March 2006

1686 Françoise Forges, The Ex Ante Incentive Compatible Core in Exchange Economies with and without Indivisibilities, March 2006

1687 Assar Lindbeck, Mårten Palme and Mats Persson, Job Security and Work Absence: Evidence from a Natural Experiment, March 2006

1688 Sebastian Buhai and Coen Teulings, Tenure Profiles and Efficient Separation in a Stochastic Productivity Model, March 2006 
1689 Gebhard Kirchgaessner and Silika Prohl, Sustainability of Swiss Fiscal Policy, March 2006

1690 A. Lans Bovenberg and Peter Birch Sørensen, Optimal Taxation and Social Insurance in a Lifetime Perspective, March 2006

1691 Moritz Schularick and Thomas M. Steger, Does Financial Integration Spur Economic Growth? New Evidence from the First Era of Financial Globalization, March 2006

1692 Burkhard Heer and Alfred Maussner, Business Cycle Dynamics of a New Keynesian Overlapping Generations Model with Progressive Income Taxation, March 2006

1693 Jarko Fidrmuc and Iikka Korhonen, Meta-Analysis of the Business Cycle Correlation between the Euro Area and the CEECs, March 2006

1694 Steffen Henzel and Timo Wollmershaeuser, The New Keynesian Phillips Curve and the Role of Expectations: Evidence from the Ifo World Economic Survey, March 2006

1695 Yin-Wong Cheung, An Empirical Model of Daily Highs and Lows, March 2006

1696 Scott Alan Carson, African-American and White Living Standards in the $19^{\text {th }}$ Century American South: A Biological Comparison, March 2006

1697 Helge Berger, Optimal Central Bank Design: Benchmarks for the ECB, March 2006

1698 Vjollca Sadiraj, Jan Tuinstra and Frans van Winden, On the Size of the Winning Set in the Presence of Interest Groups, April 2006

1699 Martin Gassebner, Michael Lamla and Jan-Egbert Sturm, Economic, Demographic and Political Determinants of Pollution Reassessed: A Sensitivity Analysis, April 2006

1700 Louis N. Christofides and Amy Chen Peng, Major Provisions of Labour Contracts and their Theoretical Coherence, April 2006

1701 Christian Groth, Karl-Josef Koch and Thomas M. Steger, Rethinking the Concept of Long-Run Economic Growth, April 2006

1702 Dirk Schindler and Guttorm Schjelderup, Company Tax Reform in Europe and its Effect on Collusive Behavior, April 2006

1703 Françoise Forges and Enrico Minelli, Afriat's Theorem for General Budget Sets, April 2006

1704 M. Hashem Pesaran, Ron P. Smith, Takashi Yamagata and Liudmyla Hvozdyk, Pairwise Tests of Purchasing Power Parity Using Aggregate and Disaggregate Price Measures, April 2006

1705 Piero Gottardi and Felix Kubler, Social Security and Risk Sharing, April 2006 
1706 Giacomo Corneo and Christina M. Fong, What's the Monetary Value of Distributive Justice?, April 2006

1707 Andreas Knabe, Ronnie Schoeb and Joachim Weimann, Marginal Employment Subsidization: A New Concept and a Reappraisal, April 2006

1708 Hans-Werner Sinn, The Pathological Export Boom and the Bazaar Effect - How to Solve the German Puzzle, April 2006

1709 Helge Berger and Stephan Danninger, The Employment Effects of Labor and Product Markets Deregulation and their Implications for Structural Reform, May 2006

1710 Michael Ehrmann and Marcel Fratzscher, Global Financial Transmission of Monetary Policy Shocks, May 2006

1711 Carsten Eckel and Hartmut Egger, Wage Bargaining and Multinational Firms in General Equilibrium, May 2006

1712 Mathias Hoffmann, Proprietary Income, Entrepreneurial Risk, and the Predictability of U.S. Stock Returns, May 2006

1713 Marc-Andreas Muendler and Sascha O. Becker, Margins of Multinational Labor Substitution, May 2006

1714 Surajeet Chakravarty and W. Bentley MacLeod, Construction Contracts (or "How to Get the Right Building at the Right Price?”), May 2006

1715 David Encaoua and Yassine Lefouili, Choosing Intellectual Protection: Imitation, Patent Strength and Licensing, May 2006

1716 Chris van Klaveren, Bernard van Praag and Henriette Maassen van den Brink, Empirical Estimation Results of a Collective Household Time Allocation Model, May 2006

1717 Paul De Grauwe and Agnieszka Markiewicz, Learning to Forecast the Exchange Rate: Two Competing Approaches, May 2006

1718 Sijbren Cnossen, Tobacco Taxation in the European Union, May 2006

1719 Marcel Gérard and Fernando Ruiz, Interjurisdictional Competition for Higher Education and Firms, May 2006

1720 Ronald McKinnon and Gunther Schnabl, China's Exchange Rate and International Adjustment in Wages, Prices, and Interest Rates: Japan Déjà Vu?, May 2006 